\title{
Effect of Temperature on Cortical Infection by Plasmodiophora brassicae and Clubroot Severity
}

\author{
Kalpana Sharma, Bruce D. Gossen, and Mary Ruth McDonald
}

First and third authors: Department of Plant Agriculture, University of Guelph, Guelph, ON, N1G 2W1 Canada; and second author: Agriculture and Agri-Food Canada, Saskatoon Research Centre, Saskatoon, SK, S7N 0X2 Canada. Accepted for publication 31 July 2011.

\section{ABSTRACT}

Sharma, K., Gossen, B. D., and McDonald, M. R. 2011. Effect of temperature on cortical infection by Plasmodiophora brassicae and clubroot severity. Phytopathology 101:1424-1432.

A study was conducted to assess the effect of temperature on infection and development of Plasmodiophora brassicae in the root cortex of Shanghai pak choy (Brassica rapa subsp. chinensis) and on subsequent clubroot severity. Ten-day-old seedlings were grown individually, inoculated with resting spores, and maintained in growth cabinets at 10 , $15,20,25$, and $30^{\circ} \mathrm{C}$. Seedlings were harvested at 2-day intervals, starting 8 days after inoculation (DAI) and continuing until 42 DAI. Roots were assessed at 4-day intervals for the incidence of cortical infection and stage of infection (young plasmodia, mature plasmodia, and resting spores), at 2day intervals for symptom development and clubroot severity, and at 8- day intervals for the number of spores per gram of gall. Temperature affected every stage of clubroot development. Cortical infection was highest and symptoms were observed earliest at $25^{\circ} \mathrm{C}$, intermediate at 20 and $30^{\circ} \mathrm{C}$, and lowest and latest at $15^{\circ} \mathrm{C}$. No cortical infection or symptoms were observed at $42 \mathrm{DAI}$ in plants grown at $10^{\circ} \mathrm{C}$. A substantial delay in the development of the pathogen was observed at $15^{\circ} \mathrm{C}$. Resting spores were first observed at $38 \mathrm{DAI}$ in plants at $15^{\circ} \mathrm{C}, 26 \mathrm{DAI}$ at 20 and $30^{\circ} \mathrm{C}$, and $22 \mathrm{DAI}$ at $25^{\circ} \mathrm{C}$. The yield of resting spores from galls was higher in galls that developed at 20 to $30^{\circ} \mathrm{C}$ than those that developed at $15^{\circ} \mathrm{C}$ over 42 days of assessment. These results support the observation in companion studies that cool temperatures result in slower development of clubroot symptoms in brassica crops, and demonstrate that the temperature has a consistent pattern of effect throughout the life cycle of the pathogen.
Clubroot, caused by the soilborne obligate parasite Plasmodiophora brassicae Woronin, is an important disease of brassica crops in many regions of the world (8). The life cycle of $P$. brassicae consists of two phases, a primary phase that is restricted to root hairs (and occasionally epidermal cells) that concludes with production of secondary zoospores, and a secondary phase where the root cortex is infected, which results in the development of secondary plasmodia and galls $(15,16)$. When secondary zoospores are released from root hairs at the end of primary infection, they fuse and then penetrate cortical cells and develop into secondary plasmodia. Secondary plasmodia proliferate in roots and plant hormone metabolism, especially auxin and cytokinin, is altered that causes cellular hypertrophy and hyperplasia in the root tissues, resulting in gall formation $(15,16,29)$. The young secondary plasmodia initially contain two nuclei, but develop into multinuclear plasmodia called mature secondary plasmodia $(16,21,29)$. Mature secondary plasmodia develop into resting spores (16) that fill the gall. The resting spores are subsequently released from rotting galls into the soil, where they can remain viable for 20 years or more (30).

Temperatures between 16 and $21^{\circ} \mathrm{C}$ or at or over $14^{\circ} \mathrm{C}$ have been reported to be satisfactory for the germination of resting spores $(5,10,14,31)$ and several studies have reported the effect of temperature on the incidence and severity of clubroot symptoms on brassica crops $(1,4,6,20,30)$. Temperatures below $17^{\circ} \mathrm{C}$ are associated with low infection of root hairs and limited development of clubroot in seedlings and older plants $(11,12)$. A detailed assessment of the effect of temperature on root hair infection during

Corresponding author: M. R. McDonald; E-mail address: mrmcdona@uoguelph.ca

doi:10.1094/PHYTO-04-11-0124

(C) Her Majesty the Queen in Right of Canada, as represented by the Minister of Agriculture and Agri-Food Canada. seedling germination and establishment further demonstrated that low temperatures reduce infection frequency and slow pathogen development in root hairs (23). Root hairs could be infected by $P$. brassicae at the lowest temperature examined $\left(10^{\circ} \mathrm{C}\right)$, but production of secondary zoospores occurred only above $15^{\circ} \mathrm{C}$, so no clubroot symptoms developed at 10 and $15^{\circ} \mathrm{C}$. This effect of temperature on primary infection represents one mechanism that underlies observations that low temperatures slow the development of clubroot in brassica crops $(1,11,12,20)$. However, no comparable information is available on the effect of temperature on cortical infection.

The present study was undertaken to examine the effects of temperature on the incidence of cortical infection, the occurrence of the various developmental stages of $P$. brassicae in cortical cells, symptom development, and severity of clubroot on a model crop, Shanghai pak choy (B. rapa L. subsp. chinensis (Rupr.) var. communis Tsen and Lee).

\section{MATERIALS AND METHODS}

Plants, inoculum, inoculation, and incubation. Plants were grown in root-trainers, which have six compartments for individual seedlings (each 2.2 by 2.2 by $10 \mathrm{~cm}^{3}$ ). Seeds of Shanghai pak choy cultivar Mei Quing Choy (Stokes Seeds Ltd., Ont., Canada) were sown on moist sand in petri dishes at $20^{\circ} \mathrm{C}$ with a 16-h photoperiod. When the cotyledons were fully expanded (3 days after sowing), each seedling was transplanted into a chamber of a root-trainer containing soilless potting mixture (Sunshine mix No. 4, Sun Gro Horticulture Canada Ltd., Spruce Grove, AB). Each plant was watered daily with demineralized water adjusted to $\mathrm{pH} 6.3$ using commercial vinegar (5\% acetic acid) and fertilized weekly with $20 \mathrm{ml}$ of mineral fertilizer (urea) adjusted to pH 6.3 (80 g of 15:15:18 NPK fertilizer per liter, $5 \mathrm{ml} \mathrm{liter}^{-1}$ ) (Plant Products Co. Ltd., CA). Plants were maintained in growth cabinets at $20^{\circ} \mathrm{C}$ (14-h photoperiod, $65 \%$ relative humidity [RH]) 
for 1 week to facilitate establishment of a robust root system in the growing media prior to treatment.

Inoculum was prepared from clubroot galls on cabbage $(B$. oleracea L. var. capitata L. 'Saratoga') grown at the Muck Crops Research Station, Holland Marsh, ON, Canada $\left(44^{\circ} 5^{\prime} \mathrm{N}, 79^{\circ}\right.$ $35^{\prime} \mathrm{W}$ ) in 2008 . The predominant pathotype in this soil is pathotype 6 as classified on the differential set of Williams, or ECD $16 / 0 / 14$ using the ECD set (25). Galls were washed and stored at $-20^{\circ} \mathrm{C}$. Spores were extracted by thawing the frozen galls at room temperature, and then homogenizing $3 \mathrm{~g}$ of gall in $100 \mathrm{ml}$ of water at high speed for $2 \mathrm{~min}$ and straining the resulting spore suspension through eight layers of cheesecloth. The spore concentration was determined with a hemacytometer and adjusted to $1 \times 10^{8}$ resting spores $\mathrm{ml}^{-1}$. Freshly prepared inoculum was used for each inoculation. Ten-day-old seedlings were inoculated by pipetting $800 \mu \mathrm{l}$ of spore suspension containing $1 \times 10^{8}$ spores $\mathrm{ml}^{-1}$ onto the soil surface at the base of each seedling at 7 days after transplanting. Control plants were inoculated with sterile water. To avoid the contamination of inoculum, separate roottrainers were used for control and inoculated plants but were kept under identical conditions at which the inoculated plants were grown. A high inoculum pressure was used to ensure that a high proportion of susceptible roots would be infected. Differences in infection therefore reflect the interaction of plant and pathogen, rather than differences in the ratio of zoospores to roots. After inoculation, the seedlings were transferred to growth cabinets at each of five temperatures: $10,15,20,25$, and $30^{\circ} \mathrm{C}\left( \pm 1^{\circ} \mathrm{C}\right)$ at 14 -h photoperiod and $65 \% \mathrm{RH}$ for the duration of the experiment. Temperature and $\mathrm{RH}$ were recorded hourly using data loggers (Hobo; Onset Computer Corp., CA).

Cortical infection. The extent of cortical infection was assessed for each plant based on assessment of root sections obtained using a slight modification of the method of Kobelt et al. (17). At each sampling date, four root-trainers were chosen at random to provide four plants for the assessment (one plant per experimental unit, four reps). The roots were sampled at 4-day intervals between 10 and 42 DAI, washed, and placed in a fixative solution (1:1, 95\% acetic acid: 95\% ethanol). Samples were cut in transverse sections of $0.5-\mathrm{cm}$-long root segments from the top 0 to $1 \mathrm{~cm}$ of the main taproot. The tissue was dehydrated through an ethanol series and then embedded in paraffin. Cross-sections (6- $\mu \mathrm{m}$ thick) were cut with a microtome and stained with methylene blue. Development of P. brassicae was classified based on the developmental stages: (i) young plasmodia, (ii) mature plasmodia, and (iii) resting spores (Fig. 1). Young plasmodia were identified as small and roughly spherical, staining medium blue within the cells, while mature plasmodia were identified as large irregular shapes that stained dark blue within the cells. Resting spores were masses of distinct spherical bodies that stained dark blue. The number of cells that contained plasmodia or resting spores in each microscope field at $\times 125$ magnification was counted in five fields of view within one section from each root. In addition, cortical infection (\%) was estimated using image analysis for each field of view. Briefly, the area (\%) occupied by plasmodia and resting spores was estimated in digital images of each microscope field at $\times 125$ magnification using Assess image analysis software (The American Phytopathological Society, St. Paul, MN). For each image, separation of infected and healthy areas of the image requires that the two components differ in properties such as color or brightness. Staining with methylene blue served this purpose because plasmodia and resting spores stained a much darker blue than the cell walls of the root cells. Initially, the software selects the color and brightness for the entire image. The infected area is separated from the background by applying an overlay, which highlights the selected area based on a selected threshold of difference in color and brightness. Some image enhancement was done to optimize measurements because of inconsistency in lighting among images, slight differ- ences in the color of healthy tissue, and variation in stain intensity. These are applied on a case by case basis and were used to consistently enhance the entire area of interest to maintain measurement accuracy. Once each image was optimized, the percent area of cortical infection was calculated. The experiment was repeated.

Symptom development and clubroot severity. Seedlings were harvested at 2-day intervals starting 8 days after inoculation (DAI) to a maximum of 42 DAI. At each sampling date, four roottrainers were chosen at random to provide 12 plants for the assessment (three plants per experimental unit, four reps). Each plant was uprooted, and its roots were rinsed, cleaned using a soft brush, and blotted dry with tissue paper. The main roots of each plant were assessed for symptom development and the day when the swelling of the taproot and hypocotyl were first observed was recorded. Clubroot severity was rated using a 0 to 3 scale to separate the roots into classes, where $0=$ no galling, $1=$ incipient galling (small galls on less than $1 / 3$ of roots), $2=$ moderate galling (small- to medium-sized galls on $1 / 3$ to $2 / 3$ of roots), and $3=$ severe galling (medium- to large-sized galls on more than $2 / 3$ of roots) (19). The experiment was repeated. A disease severity index (DSI) was calculated using the formula of Kobriger and Hagedorn (18) as follows.

$$
\text { DSI }=\frac{\Sigma[(\text { class no. })(\text { no. } \text { of plants in each class })]}{(\text { total no. of plants per sample })(\text { no. of classes }-1)} \times 100
$$

Quantification of resting spores. Infected roots (1 g) from the top 0 to $1 \mathrm{~cm}$ of the main taproot were macerated in $1 \mathrm{ml}$ of tap water for $40 \mathrm{~s}$ using Thermo Savant FastPrep FP120/BIO101 (Fisher Scientific Ltd., Canada). The homogenate was then mixed with $9 \mathrm{ml}$ of demineralized water and the resulting spore suspension was strained through layers of cheesecloth. The spore number was determined with a hemacytometer. Root samples before 22 DAI did not contain resting spores. Data for quantification of spores were obtained between 22 to 42 DAI at 8-day intervals. There were four replications for each temperature and sample day with three plants per experimental unit, and the experiment was repeated.

Statistical analysis. Data analyses were conducted using SAS statistical software (SAS Institute, Inc., 2010, Cary, NC). There were no repetition or repetition-temperature interaction effects in the analysis of variance (ANOVA), so the data from both repetitions of each trial were pooled for analysis. Data were investigated using ANOVA and linear and polynomial regression procedures. The pattern of response to the temperature treatments was estimated using single-degree-of-freedom contrasts to detect linear and quadratic relationships. Where these assessments identified a significant effect of temperature, that effect was described using regression. Quadratic, cubic, exponential, and sigmoid regressions were carried out in the beginning, but they did not result in a better description of the relationship between parameters compared with linear or quadratic regressions. A simple quadratic equation was chosen to describe the relationships between temperature and cortical infection, DSI, and spore number per gram of gall. Regression analysis was also used to quantify the relationships among the area of cortical infection, DSI, and the number of spores per gram of gall. For the uniformity of presentation, four data points for each temperature treatment, each representing 22, 30, 38, and 42 DAI were selected for the analysis of data. Prior to analysis, percent data were arcsine-transformed when necessary to improve the normality and homogeneity of variance, but nontransformed means are presented for uniformity of presentation.

\section{RESULTS}

Cortical infection. Young plasmodia were small and roughly spherical in shape (Fig. 1A). The young plasmodia proliferated 

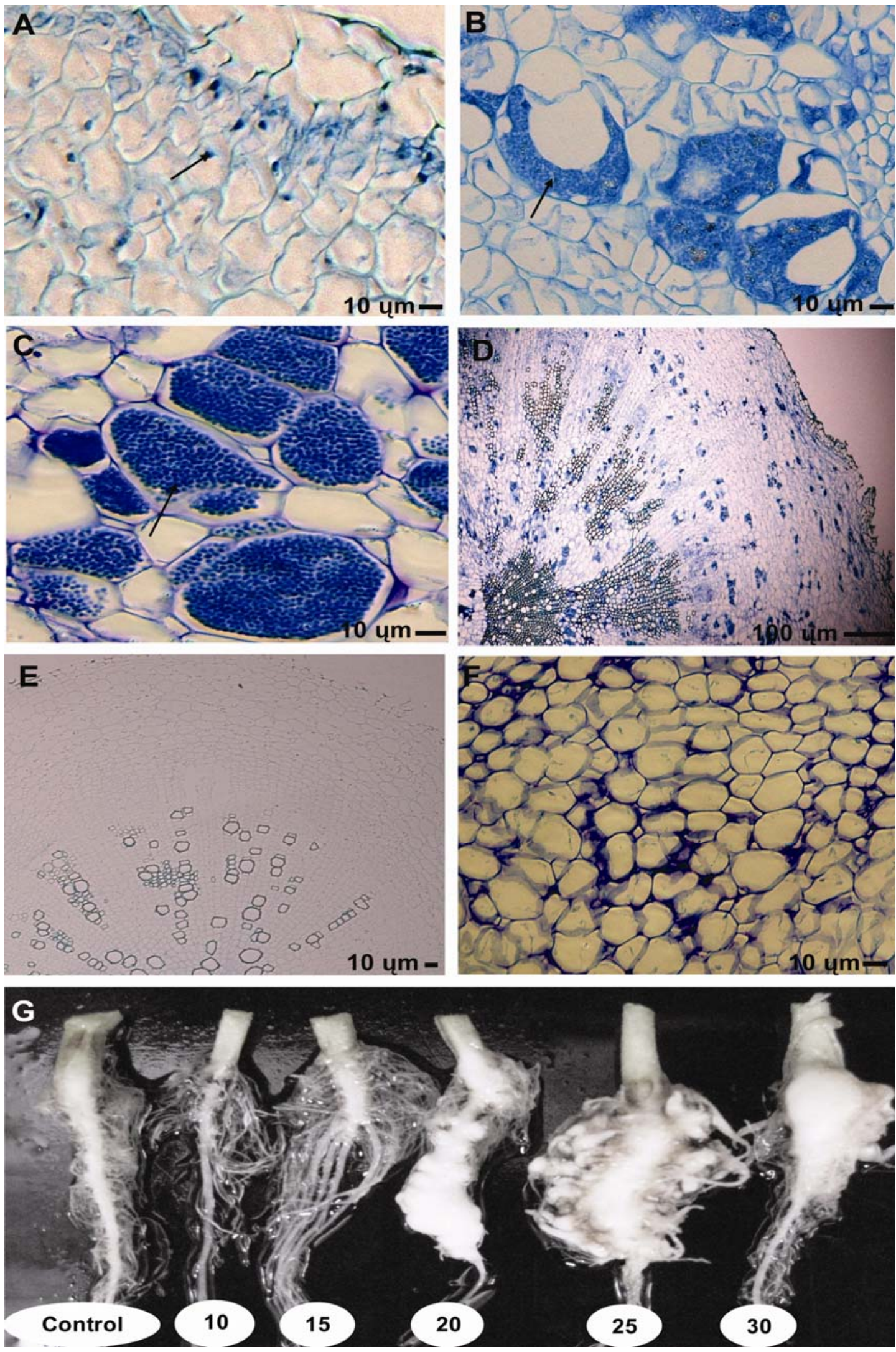

Fig. 1. Stages of secondary infection of Plasmodiophora brassicae in cross-sections of the root cortex of Shanghai pak choy stained with methylene blue: A, young plasmodia (arrow), B, mature plasmodia in hypertrophied cell (arrow), C, resting spores in cortical cells (arrow), D, root sampled at gall initiation; plasmodia are distributed throughout the tissue and there is no distinct cortex or stele. Note the extensive cell division and cells enlargement. E, Healthy root showing distinct regions of cortex and stele divided by the endodermis, $\mathbf{F}$, healthy root showing small, uniform cells, and $\mathbf{G}$, effect of temperature ( 10 to $\left.30^{\circ} \mathrm{C}\right)$ on clubroot severity at 22 days after inoculation. 
and forming clusters, followed by the development of mature plasmodia (Fig. 1B). Mature plasmodia were generally much larger and irregular in shape. Resting spores developed from the cleavage of mature plasmodia. Resting spores were round and distinct (Fig. 1C).

Microscopic study of stained root sections revealed that temperature had a large effect on the development of $P$. brassicae within the root cortex. Infection and development of the pathogen in the root cortex was followed in roots grown at 15 to $30^{\circ} \mathrm{C}$ (Fig.
2). No cortical infection was present at $10^{\circ} \mathrm{C}$. The extent of cortical infection increased as the temperature increased above $15^{\circ} \mathrm{C}$. Infected cells were first observed at $10 \mathrm{DAI}$ in plants at 20 to $30^{\circ} \mathrm{C}$, and at $22 \mathrm{DAI}$ in plants at $15^{\circ} \mathrm{C}$. The increase in root area infected was roughly linear over time but occurred at different rates for different temperatures. In plants at $25^{\circ} \mathrm{C}$, cortical infection was $2 \%$ at $10 \mathrm{DAI}$ and increased to $37 \%$ by $42 \mathrm{DAI}$. There was initially little or no difference in cortical infection between the 20 and $30^{\circ} \mathrm{C}$ treatments, but cortical infection at $20^{\circ} \mathrm{C}$
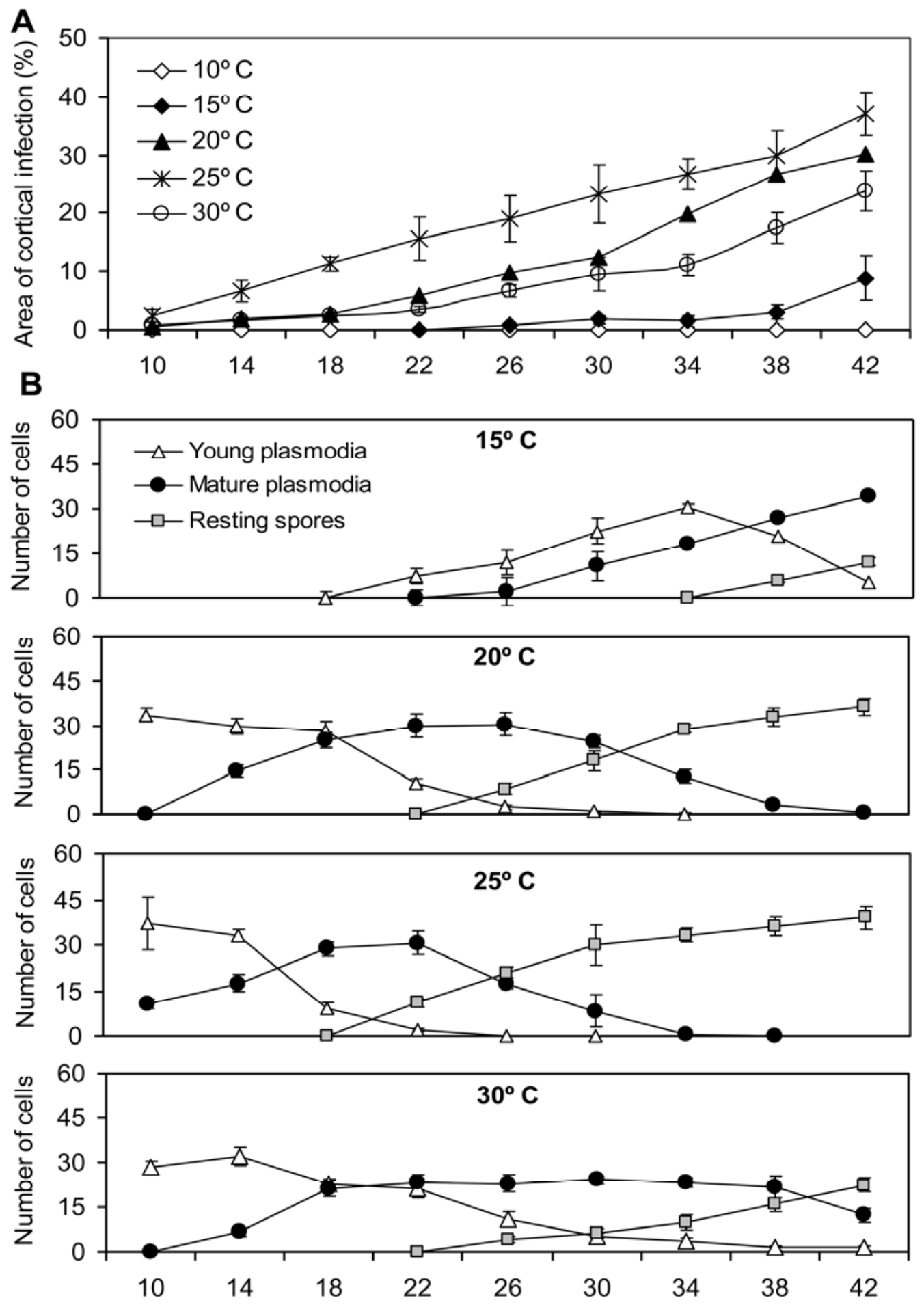

Days after inoculation

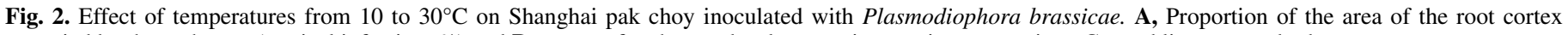
occupied by the pathogen (cortical infection, \%) and $\mathbf{B}$, stages of pathogen development in root tissue over time. Capped lines $=$ standard error. 
was slightly higher from 34 to 42 DAI (Fig. 2A). Cortical infection at $42 \mathrm{DAI}$ was $30 \%$ at $20^{\circ} \mathrm{C}$ and $24 \%$ at $30^{\circ} \mathrm{C}$. In contrast, cortical infection remained very low at $15^{\circ} \mathrm{C}$, reaching a maximum of $9 \%$ at 42 DAI. The effect of temperature on cortical infection at 42 DAI was quadratic, with an optimum temperature of $24.4^{\circ} \mathrm{C}\left(y=-0.04 x^{2}+1.84 x-16.2\right.$, where $y=$ cortical infection and $x=$ temperature; $R^{2}=0.88 ; P<0.001$ ) (Fig. 3).

Young plasmodia, mature plasmodia, and resting spores were observed in the root cortex of plants grown at temperatures from 15 to $30^{\circ} \mathrm{C}$, but were not present at $10^{\circ} \mathrm{C}$ (Fig. $2 \mathrm{~B}$ ). The numbers of cells per field of view containing the developmental stages of secondary infection (young plasmodia, mature plasmodia, and resting spores) of $P$. brassicae at $10 \mathrm{DAI}$ were highest at $25^{\circ} \mathrm{C}$ (48 cells), lower at $20^{\circ} \mathrm{C}$ ( 34 cells), and lowest at $30^{\circ} \mathrm{C}$ (29 cells) at $10 \mathrm{DAI}$, but the number of infected cells do not differ after $22 \mathrm{DAI}$ in the temperature range of 20 to $30^{\circ} \mathrm{C}$ ( 41 cells at $20^{\circ} \mathrm{C}$, 44 cells at $25^{\circ} \mathrm{C}$, and 45 cells at $30^{\circ} \mathrm{C}$ ) (Fig. 2B). In contrast, the number of infected cells per field of view at $15^{\circ} \mathrm{C}$ increased slowly, appearing first at 22 DAI (7 cells) and increasing overtime to a maximum at 34 DAI (49 cells) that was higher than the number of infected cells at other temperature (Fig. 2B).

Young plasmodia were first observed at $10 \mathrm{DAI}$ at 20 to $30^{\circ} \mathrm{C}$, and at $22 \mathrm{DAI}$ at $15^{\circ} \mathrm{C}$ (Fig. 2B). At 15 and $30^{\circ} \mathrm{C}$, young plasmodia were still present in roots until 42 DAI. In contrast, young plasmodia were present only until $22 \mathrm{DAI}$ at $25^{\circ} \mathrm{C}$, after which time only resting spores could be seen. Mature plasmodia were first detected in the root cortex at $10 \mathrm{DAI}$ at $25^{\circ} \mathrm{C}$ ( 16 cells per field of view), at $14 \mathrm{DAI}$ at $20^{\circ} \mathrm{C}\left(15\right.$ cells) and $30^{\circ} \mathrm{C}$ ( 7 cells), and at $26 \mathrm{DAI}$ at $15^{\circ} \mathrm{C}$ (3 cells). Differentiation of mature plasmodia into resting spores was not affected by temperature and occurred 12 days after the first occurrence of mature plasmodia at temperatures from 15 to $30^{\circ} \mathrm{C}$. In the period from 26 to $42 \mathrm{DAI}$, the number of cells with resting spores increased from 8.5 to 36.5 at $20^{\circ} \mathrm{C}$ and 4.2 to 22.4 at $30^{\circ} \mathrm{C}$. The transition from mature plasmodia to resting spores was complete at $34 \mathrm{DAI}$ at $25^{\circ} \mathrm{C}$ and $42 \mathrm{DAI}$ at $20^{\circ} \mathrm{C}$, but at 15 and $30^{\circ} \mathrm{C}$ the transition was still not completed when the trial was terminated at 42 DAI.

The gross anatomy of root tissues in the noninoculated controls was not affected by temperature in this study, but as expected, infection by $P$. brassicae resulted in severe distortion of root growth and development. At $10^{\circ} \mathrm{C}$, both noninoculated and inoculated roots had distinct regions of cortical cells, endodermis, and stele. In inoculated roots where swelling symptoms were just beginning to develop, cortical cells looked similar to those in the noninoculated roots, although the cortical cells were highly plasmolysed. In contrast, the endodermis and stele exhibited signs of disruption and abnormal cell division (Fig. 1D, E, and F). The cellular organization within infected roots broke down as symptoms developed (Fig. 1F). The cortical cells of the infected roots became enlarged and intermingled with the secondary phloem, and the distinct organization of tissues into cortex, endodermis and stele was lost. Based on visual observation, infected cells were much larger than the corresponding cells of the noninoculated roots, and even cells without plasmodia in the galled roots tended to be larger than the cells of the noninoculated root.

Symptom development and clubroot severity. Temperature also had an effect on symptom development and clubroot severity. Clubroot symptoms (swelling and abnormal growth of root tissues) developed earlier and were more severe in plants grown at temperatures above $15^{\circ} \mathrm{C}$ than at 10 or $15^{\circ} \mathrm{C}$. Swelling of the taproot was visible at $10 \mathrm{DAI}$ in plants at $25^{\circ} \mathrm{C}$, at $14 \mathrm{DAI}$ at 20 and $30^{\circ} \mathrm{C}$, and at $28 \mathrm{DAI}$ at $15^{\circ} \mathrm{C}$. No symptoms of clubroot were present at $10^{\circ} \mathrm{C}$ when the trial was terminated at $42 \mathrm{DAI}$ (Fig. 4). Clubroot severity increased quickly at $25^{\circ} \mathrm{C}$ and more slowly at 20 and $30^{\circ} \mathrm{C}$, with a DSI rating of 100 first observed at 22 DAI in plants at $25^{\circ} \mathrm{C}$, at $30 \mathrm{DAI}$ at $30^{\circ} \mathrm{C}$, and at $32 \mathrm{DAI}$ at $20^{\circ} \mathrm{C}$. In contrast, clubroot severity at $15^{\circ} \mathrm{C}$ developed very slowly to a maximum DSI of 47 at 42 DAI (Fig. 4). There was a quadratic relationship between temperature and severity at 22 DAI (when DSI first reached 100 at $25^{\circ} \mathrm{C}$ ): $y=-0.025 x^{2}+1.54 x-14.3$, where $y=$ DSI and $x=$ temperature $\left(R^{2}=0.80 ; P<0.01\right)$ with an optimum temperature of $25.6^{\circ} \mathrm{C}$ (Fig. 5).

The area of cortical infection was strongly and positively correlated with DSI but had a lower linear coefficient of regression $\left(R^{2}=0.60 ; P<0.01\right)$ (Fig. 6A). The maximum possible clubroot severity (DSI of 100) was obtained at $10 \%$ cortical infection; and the rate of cortical infection increase was high at $25^{\circ} \mathrm{C}$.

Quantification of resting spores. Temperature affected the number of resting spores per gram of gall. Resting spore concentration increased linearly over time at the optimum temperature of $25^{\circ} \mathrm{C}$, and progressively more slowly at 20,30 , and $15^{\circ} \mathrm{C}$ (Fig. 7). At $25^{\circ} \mathrm{C}$, substantial quantities of resting spores $\left(5.7 \times 10^{7}\right.$ spores $\left.\mathrm{g}^{-1}\right)$ were first observed at $22 \mathrm{DAI}$ and increased to $23.2 \times 10^{7}$ by 42 DAI. At 30 DAI, spore concentration was $7.5 \times 10^{7}$ spores $\mathrm{g}^{-1}$ at $20^{\circ} \mathrm{C}$ and $5.7 \times 10^{7}$ spores $\mathrm{g}^{-1}$ at $30^{\circ} \mathrm{C}$. At $42 \mathrm{DAI}$, spore concentration was $13.3 \times 10^{7}$ spores $\mathrm{g}^{-1}$ at $20^{\circ} \mathrm{C}$ and $7.9 \times 10^{7}$

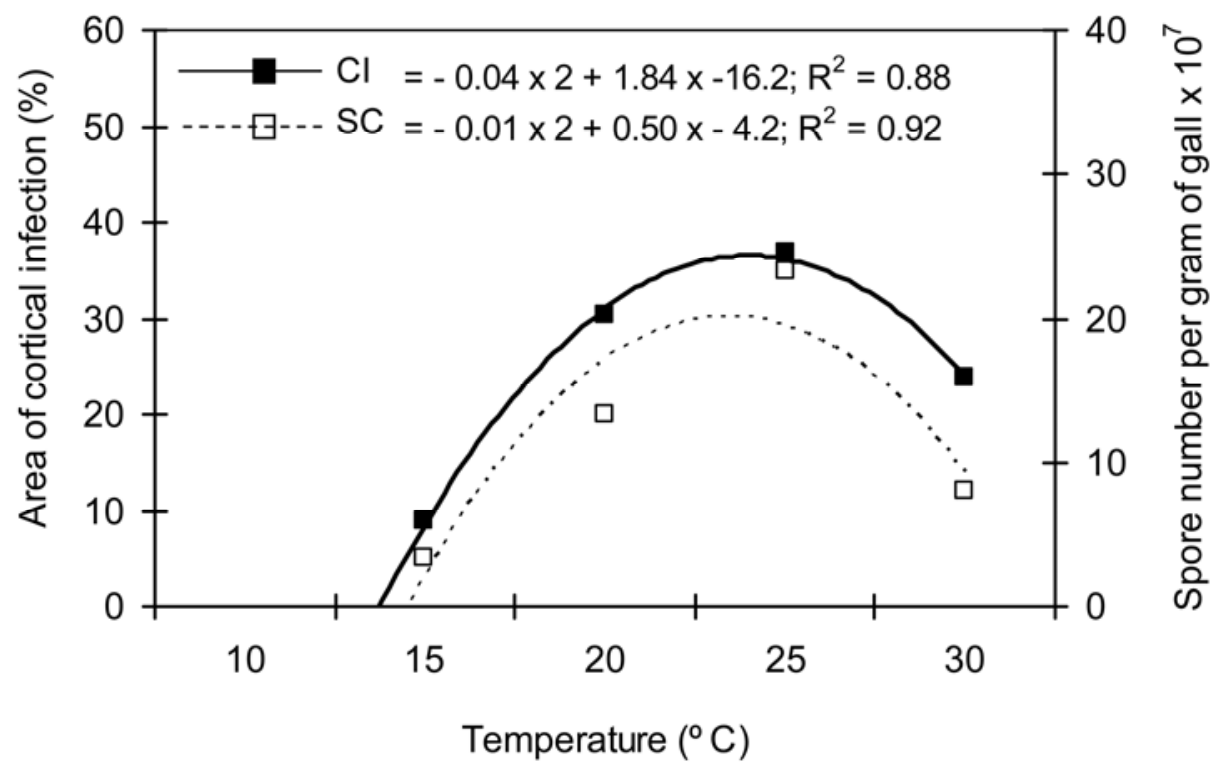

Fig. 3. Effect of temperature on the proportion of the area of the root cortex occupied by the pathogen (cortical infection, \%) and number of spores per gram of gall at 42 days after inoculation. Curves are only meant to show responses, in their general pattern. 
spores $\mathrm{g}^{-1}$ at $30^{\circ} \mathrm{C}$. In contrast, the transition to resting spores occurred slowly at $15^{\circ} \mathrm{C}$; resting spores were first observed at 38 DAI $\left(2.9 \times 10^{7}\right.$ spores $\left.\mathrm{g}^{-1}\right)$ and increased very slowly to $3.4 \times$ $10^{7}$ spores $\mathrm{g}^{-1}$ at $42 \mathrm{DAI}$. There was a quadratic relationship between temperature and spore concentration at 42 DAI $\left(R^{2}=\right.$ $0.92 ; P<0.01$ ) (Fig. 3). Similarly, regression analysis indicated a positive linear relationship between spore concentration and the area of cortical infection $\left(R^{2}=0.89 ; P<0.01\right)$ and between spore concentration and the DSI $\left(R^{2}=0.59 ; P<0.01\right)$ (Fig. 6B and C). The main difference was that no resting spores were detected from the gall at DSI of 53 and 58 from plants at 20 and $30^{\circ} \mathrm{C}$ at 22 DAI, respectively. In contrast, substantial levels of resting spores $\left(2.9 \times 10^{7}\right.$ spores $\left.\mathrm{g}^{-1}\right)$ were observed at DSI of 22 from plants at $15^{\circ} \mathrm{C}$ at $38 \mathrm{DAI}$.

\section{DISCUSSION}

Temperature affected every aspect of the development of $P$. brassicae in root tissues, including the number of cortical cells infected, the area of root cortex that was colonized, pathogen development, symptom initiation, clubroot severity, and number of spores per gram of gall. Infection of cortical cells was observed in plants at 15 to $30^{\circ} \mathrm{C}$, but no cortical infection or clubroot symptoms were present at $42 \mathrm{DAI}$ (when the trial was terminated) in inoculated plants grown at $10^{\circ} \mathrm{C}$. Cortical infection, number of spores per gram of gall weight, and severity were highest at $25^{\circ} \mathrm{C}$, intermediate at 20 and $30^{\circ} \mathrm{C}$, and lowest at $15^{\circ} \mathrm{C}$ over 42 days of assessment. Also, there was a strong positive correlation between cortical infection at 15 to $30^{\circ} \mathrm{C}$ and both final clubroot severity and number of spores per gram of gall (Fig. 6). The effect of temperature on spore germination $(5,15,31)$, root hair infection (23), and symptom development $(1,20,28)$ has been examined before, but this is the first detailed report on the effect of temperature on the development of $P$. brassicae within the root cortex.

The stages of secondary infection by $P$. brassicae have been examined in several brassica crops $(2,9,16,21,29)$. As expected, the developmental stages observed in Shanghai pak choy in the current study were similar to those in other hosts. However, previous studies utilized a single temperature, usually selected to be close to the temperature optimum for the pathogen. The results from the current study demonstrate that secondary infections of cortical cells are initiated quickly in a highly susceptible host such as Shanghai pak choy when the temperature is optimum. At 20 to $30^{\circ} \mathrm{C}$, substantial numbers of cells contained young plasmodia at 10 DAI (the earliest sampling date), and a few mature plasmodia were already present in plants at $25^{\circ} \mathrm{C}$. This could be interpreted as evidence that primary infection has been bypassed and that primary zoospores are infecting directly into cortical tissues. However, we found no clear indication of direct infection of the root cortex by primary zoospores in a detail assessment of primary infection (23).

The timing of cortical infection differs in various hosts and also depends on the pathotypes or isolates of $P$. brassicae used for inoculation. In addition, it has been shown that the temperature effect is dependent on the genotype, using an Arabidopsis wild type and a mutant that had low gall size at $24^{\circ} \mathrm{C}$, but galls comparable to wild type at $18^{\circ} \mathrm{C}$ (24). Cortical infection and young plasmodia were first observed at 4 DAI in turnip (B. rapa subsp. rapa) at $25^{\circ} \mathrm{C}(29)$. In Arabidopsis thaliana at $21^{\circ} \mathrm{C}$, young plasmodia were present at $7 \mathrm{DAI}$, mature plasmodia at $10 \mathrm{DAI}$, and mature resting spores at 17 DAI (17). In the present study, cortical infection occurred before $10 \mathrm{DAI}$ and mature plasmodia transformed into resting spores by $22 \mathrm{DAI}$ at $25^{\circ} \mathrm{C}$. This rate of development is slightly faster than that in Chinese cabbage (B. rapa subsp. pekinensis) at $26^{\circ} \mathrm{C}$, where cortical infection was present at 13 DAI and resting spores at 28 DAI (7). We selected day 10 as an initial sampling date in our study because swelling of the taproot was visible only on day 10 at $25^{\circ} \mathrm{C}$. However for future studies, it might be useful to include an earlier sampling

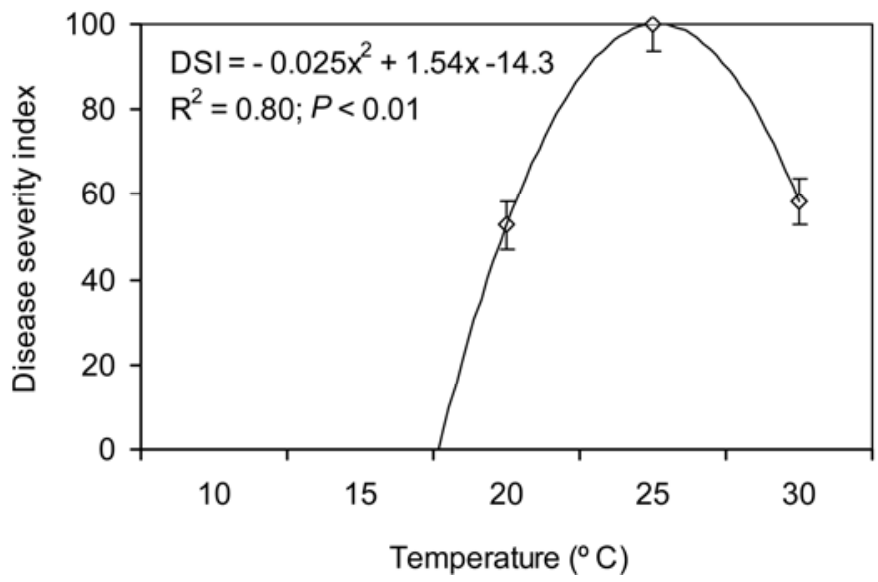

Fig. 5. Effect of temperatures from 10 to $30^{\circ} \mathrm{C}$ on clubroot severity (disease severity index) on Shanghai pak choy assessed at 22 days after inoculation. Capped lines $=$ standard error

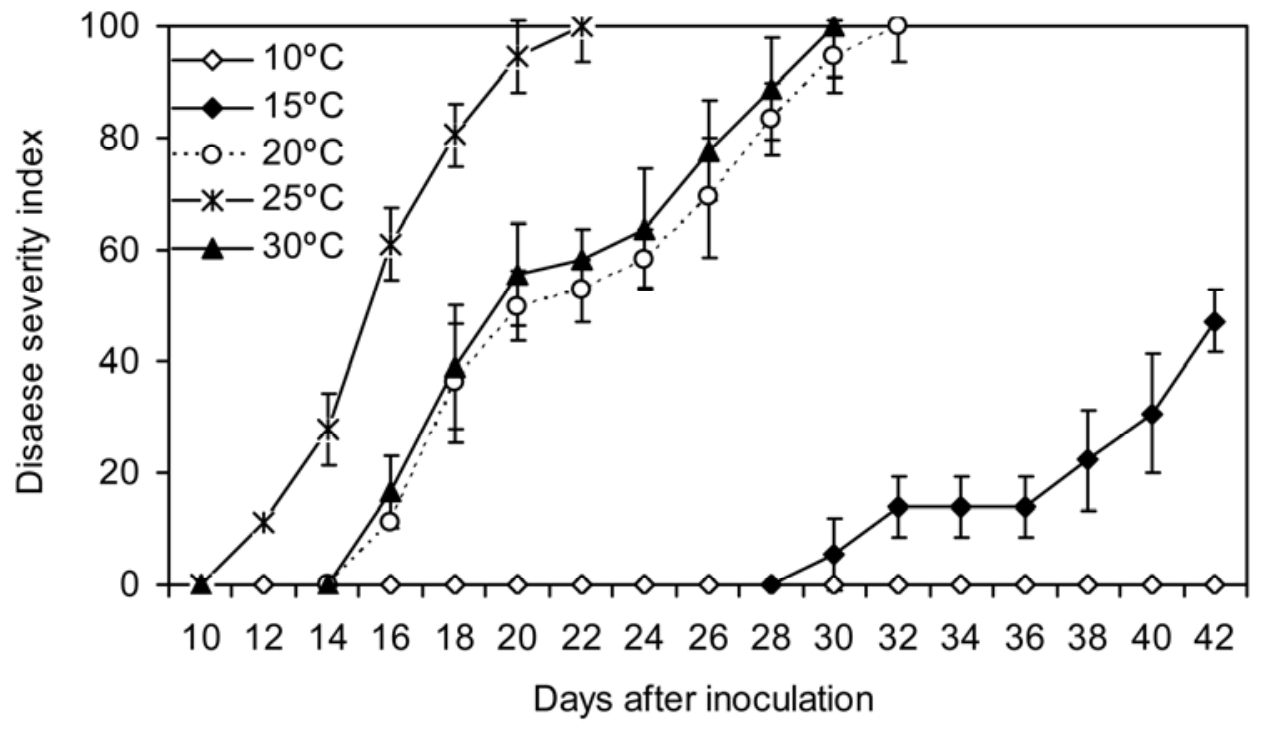

Fig. 4. Effect of temperatures from 10 to $30^{\circ} \mathrm{C}$ on clubroot severity (disease severity index) on Shanghai pak choy over time. Capped lines $=$ standard error. 

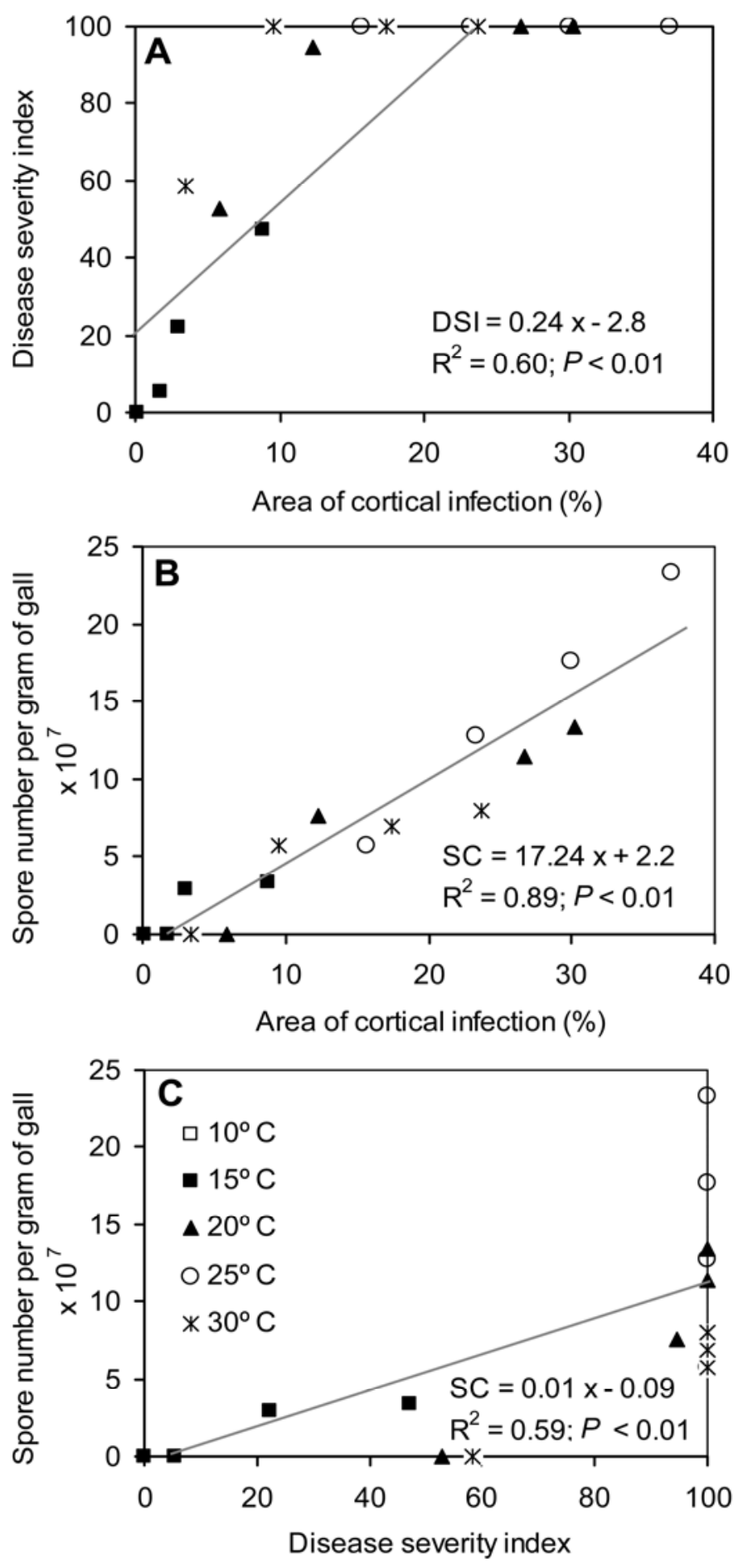

Fig. 6. Relationship between A, disease severity index (DSI) and proportion of the area of the root cortex occupied by the pathogen (cortical infection, CI), B, spores per gram of gall weight (SC) and CI, and $\mathbf{C}, \mathrm{SC}$ and DSI from 10 to $30^{\circ} \mathrm{C}$. For the uniformity of presentation, four data points for each temperature treatment, each representing $22,30,38$, and 42 DAI were selected.

date, i.e., 4 DAI, to get more qualitative information on when secondary infection can be observed.

Young plasmodia developed quickly in plants grown at 20 to $30^{\circ} \mathrm{C}$, developed slowly at $15^{\circ} \mathrm{C}$, and did not develop at $10^{\circ} \mathrm{C}$ (Fig. 2). In a companion study, root hairs were infected but secondary zoospores were not produced at $10^{\circ} \mathrm{C}$ (23). Secondary zoospores are required for cortical infection and development of secondary plasmodia $(14,21)$, so inhibition of development in root hairs at low temperature explains, at least in part, why there was no cortical infection in plants at $10^{\circ} \mathrm{C}$.
In the present study, secondary infection occurred at temperatures from 15 to $30^{\circ} \mathrm{C}$, but there were quantitative differences in the extent of colonization by $P$. brassicae with temperature. In a companion study of root hair infection (23), the initial release of secondary zoospores from root hairs occurred at $6 \mathrm{DAI}$ at $25^{\circ} \mathrm{C}$, at $8 \mathrm{DAI}$ at 20 and $30^{\circ} \mathrm{C}$, and at $16 \mathrm{DAI}$ at $15^{\circ} \mathrm{C}$, but maturation and release of secondary zoospores continued throughout the course of the 28-day experiment. The ongoing release of zoospores and resulting secondary infection of new cortical cells resulted in the presence of both plasmodia and resting spores in the same tissues (Fig. 2B). However, it is also possible that cortical infection is not solely dependent upon infection by secondary zoospores (14) or that cortical invasion could result from penetration of secondary zoospores at the base of a root hair cell (3). It seems plausible that secondary zoospores might occasionally fuse while still within the root hair and then infect the cortex without exiting the root hair. However, we did not find any direct evidence of secondary infection occurring from inside root hairs.

The change in tissue structure in infected Shanghai pak choy was similar to those observed in other Brassica species $(9,13$, $17,21)$. There was a breakdown of the cellular organization such that distinct regions of cortex, endodermis, and stele were no longer apparent. Use of digital photography and image analysis allowed us to delve deeper into this issue than has been possible before. The number of infected cells did not differ substantially after $22 \mathrm{DAI}$ at temperatures from 20 to $30^{\circ} \mathrm{C}$. Interestingly, the number of infected cells in roots grown at $15^{\circ} \mathrm{C}$ increased over time to a maximum at $34 \mathrm{DAI}$, which was higher than the number of infected cells at the other temperatures (Fig. 2B). In contrast, the proportion of the root area occupied by pathogen tissue within this temperature range was highest at $25^{\circ} \mathrm{C}$, lower at $20^{\circ} \mathrm{C}$, and lowest at $30^{\circ} \mathrm{C}$ from 34 to $42 \mathrm{DAI}$ (Fig. $2 \mathrm{~A}$ ). The secondary stage of development of $P$. brassicae is often associated with pronounced cell enlargement and cell proliferation $(17,21)$. In the current study, pathogen proliferation and development within the root cortex coincided with pronounced cell enlargement.

The yield of resting spores from galls has not previously been used to characterize disease progression. The mean number of spores observed in this study $\left(2.3 \times 10^{8}\right.$ spores $\mathrm{g}^{-1}$ at $25^{\circ} \mathrm{C}$ at 42 DAI) lies within the range of spore concentrations reported from $A$. thaliana and B. rapa at $10^{7}$ spores $\mathrm{g}^{-1}$ and Cardamine flexuosa at $10^{9}$ spores $\mathrm{g}^{-1}(24,27)$. It is generally assumed that the biomass of $P$. brassicae within a unit weight of gall is relatively constant and yields a consistent number of resting spores $(8,24)$. The current study supports this assumption in part, because there was no difference in the number of infected cells per field of view among the temperature treatments at the end of the study (42 DAI, Fig. 2B). In contrast, the proportion of the field of view made up of plasmodia and/or resting spores and the number of spores per unit of gall weight were highest near $25^{\circ} \mathrm{C}$ and lowest at $15^{\circ} \mathrm{C}$, so we conclude that spore production is higher in galls that develop at temperatures from 20 to $30^{\circ} \mathrm{C}$ than those that develop at $15^{\circ} \mathrm{C}$. However, it seems plausible that if there was more time for the pathogen to develop at $15^{\circ} \mathrm{C}$, the number of spores per gram would be the same as at higher temperatures.

Quantification of cortical infection was performed using image analysis (Assess software), and represents the first time that image analysis has been used in assessments of clubroot. This approach was effective in observing the progress of pathogen development and could provide a useful supplement to other parameters to characterize disease progression and development, e.g., disease index, number of spores per gram of gall, or the root index described by Siemens et al. (24). We believe that a similar approach could also be used to study the effect of environmental and biological factors on the infection and growth of $P$. brassicae. However, it should be noted that the histological preparation for image analysis is quite costly and labor intensive. 


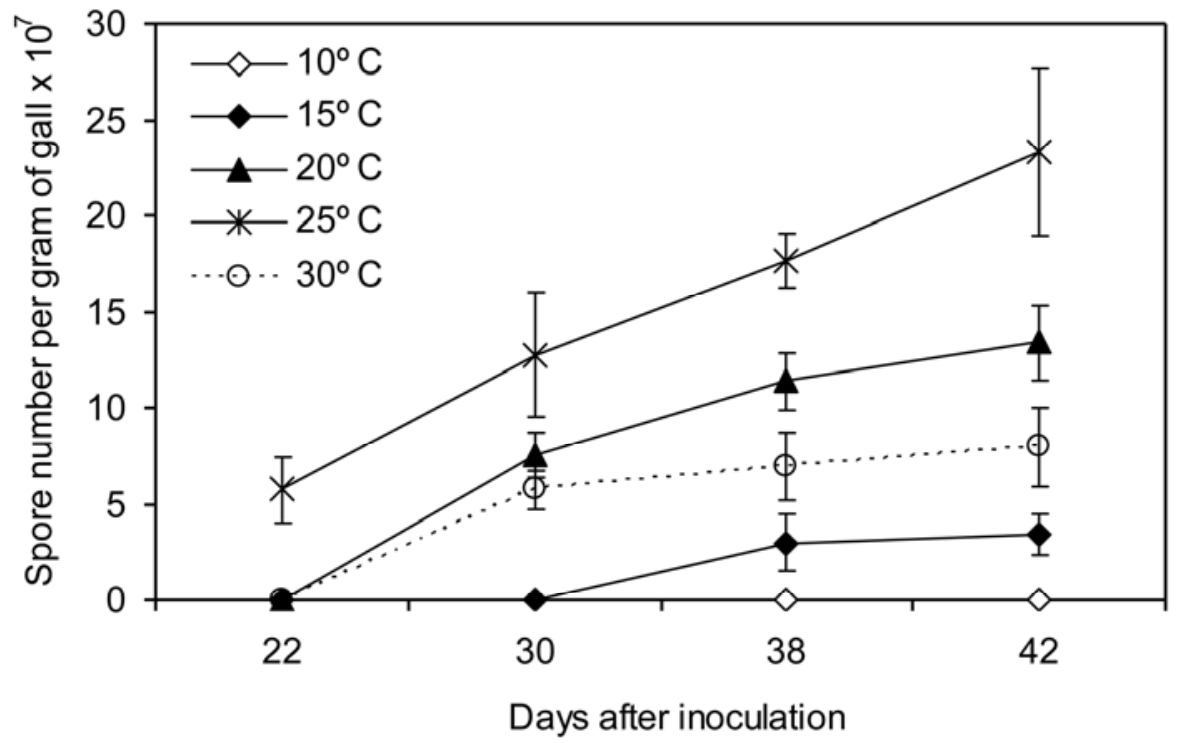

Fig. 7. Effect of temperatures from 10 to $30^{\circ} \mathrm{C}$ on number of spores per gram of gall over time. Capped lines $=$ standard error.

For studies of secondary infection where assessments are conducted on only one date, assessment at $30 \mathrm{DAI}$ at $25^{\circ} \mathrm{C}$ would be optimum under optimal conditions determined in this work. These conditions ensure a high and consistent level of cortical infection in susceptible Shanghai pak choy in the shortest possible time. To examine the stages of secondary development in a single observation, all of the stages will be present at 38, 26, 22, and 26 DAI for plants grown at $15,20,25$, and $30^{\circ} \mathrm{C}$, respectively.

Secondary infection and development can occur without resulting in macroscopic symptoms in resistant genotypes of $A$. thaliana (17) and B. oleracea (9). In one study, young plasmodia were observed at 12 DAI in clubroot-resistant Brassica genotypes but no mature plasmodia or resting spores were detected at 22 DAI (22). However, no young plasmodia or symptoms developed in a resistant line of $B$. rapa (26). These findings indicate that there may be more than one mechanism responsible for genetic resistance to clubroot. The pattern of pathogen development in the root cortex could provide some interesting insights into how and when resistance is expressed in resistant genotypes, and may help to understand the different patterns of development in these resistant lines. Studies to assess these differences are in progress in our working group.

The results of the current study demonstrate that temperature affects secondary infection by $P$. brassicae, and that under ideal moisture and $\mathrm{pH}$ conditions, secondary infection is highly correlated with subsequent symptom development and severity in a susceptible host. The effect of temperature on secondary infection represents the second mechanism that underlies the observations from field trials that low temperatures slow the development of clubroot in brassica crops $(1,12,20,28)$. However, the results of this study differ or may differ from a real field situation, because there were no circadian temperature fluctuations. Earlier research examined the effects of temperature on the development of clubroot symptoms on radish and Shanghai pak choy $(20,28)$. The field trial with pak choy identified that clubroot symptoms increased with increasing mean air temperatures from 15 to $22^{\circ} \mathrm{C}$, the highest temperature in the trial (20). A study on radishes grown on muck soil used evaluated temperature in terms of day degrees above $12.2^{\circ} \mathrm{C}$, which takes in to consideration maximum and minimum temperatures (28). In this trial there was a linear relationship between clubroot severity and soil temperature; however, no soil temperatures were reported in the study so it is not possible to determine the optimum temperature for clubroot severity on radishes in this trial. Controlled environment studies with variable temperatures can provide more information on the true effects of temperature on clubroot. These studies are underway in our working group.

\section{ACKNOWLEDGMENTS}

We thank the Clubroot Mitigation Initiative of Agriculture and AgriFood Canada, the Agriculture Development Fund of Saskatchewan, the Sustainable Production Systems Program of the OMAFRA/University of Guelph Partnership, and the University of Kassel for funding and the Animal Health Lab, University of Guelph, for root section preparation and staining.

\section{LITERATURE CITED}

1. Adhikari, K. K. C. 2010. Effect of temperature, biofungicides and fungicides on clubroot of selected brassica crops. M.Sc. Thesis. University of Guelph, Guelph, ON, Canada.

2. Agarwal, A., Kaul, V., Faggian, R., and Cahill, D. M. 2009. Development and use of a model system to monitor clubroot disease progression with an Australian field population of Plasmodiophora brassicae. Aust. Plant Pathol. 38:120-127.

3. Aist, J. R., and Williams, P. H. 1971. The cytology and kinetics of cabbage root hair penetration by Plasmodiophora brassicae. Can. J. Bot. 49:20-34.

4. Buczacki, S. T., Ockendon, J. G., and Freeman, G. H. 1978. An analysis of some effects of light and soil temperature on clubroot. Ann. App. Biol. 88:229-238.

5. Chupp, C. 1917. Studies on clubroot of cruciferous plants. Bull. Cornell Agric. Exp. Stn. 387:419-452.

6. Colhoun, J. 1953. A study of the epidemiology of club-root disease of Brassicae. Ann. Appl. Biol. 40:262-283.

7. Devos, S., Vissenberg, K., Verbelen, J. P., and Prinsen, E. 2005. Infection of Chinese cabbage by Plasmodiophora brassicae leads to a stimulation of plant growth: Impacts on cell wall metabolism and hormone balance. New Phytol. 166:241-250.

8. Dixon, G. R. 2009. Plasmodiophora brassicae in its environment. J. Plant Growth Regul. 28:212-228.

9. Donald, E. C., Jaudzems, G., and Porter, I. J. 2008. Pathology of cortical invasion by Plasmodiophora brassicae in clubroot resistant and susceptible Brassica oleracea hosts. Plant Pathol. 57:201-209.

10. Einhorn, G., and Bochow, H. 1990. The effects of temperature and $\mathrm{pH}$ value on the pathogenesis of Plasmodiophora brassicae Wor., the causal agent of clubroot. Arch. Phytopathol. Plant Prot. 26:131-138.

11. Gossen, B. D., Adhikari, K. K. C., and McDonald, M. R. 2011. Temperature influences development of clubroot under controlled conditions. Plant Pathol. doi: 10.1111/j.1365-3059.2011.02536.x.

12. Gossen, B. D., McDonald, M. R., Hwang, S. F., and Kalpana, K. C. 2009. Manipulating seeding date to minimize clubroot (Plasmodiophora brassicae) damage in canola and brassica vegetable. (Abstr.) Phytopathology 99(suppl.):S45. 
13. Graveland, R., Dale, P., and Mithen, R. 1992. Gall development in hairy root cultures infected with Plasmodiophora brassicae. Mycol. Res. 96:225-228.

14. Ikegami, H., Ito, T., Imuro, Y., and Naiki, T. 1981. Growth of Plasmodiophora brassicae (fungal disease) in the root and callus of Chinese cabbage. Pages 81-90 in: Chinese cabbage: Proc. Int. Symposium on Chinese cabbage, 1st. N. S. Talekar and T. D. Griggs, eds. Asian Vegetable Research and Development Center (AVRDC), Taiwan.

15. Ingram, D. S., and Tommerup, C. 1972. The life history of Plasmodiophora brassicae Woron. Proc. R. Soc. Lond. Ser. B 180:103-112.

16. Kageyama, K., and Asano, T. 2009. Life cycle of Plasmodiophora brassicae. J. Plant Growth Regul. 28:203-211.

17. Kobelt, P., Siemens, J., and Sacristan, M. D. 2000. Histological characterization of the incompatible interaction between Arabidopsis thaliana and the obligate biotrophic pathogen Plasmodiophora brassicae. Mycol. Res. 2:220-225.

18. Kobriger, K. M., and Hagedorn, D. J. 1983. Determination of bean root rot potential in vegetable production fields of Wisconsin's central sands. Plant Dis. 67:177-178.

19. Kuginuki, Y., Yoshikawa, H., and Hirai, M. 1999. Variation in virulence of Plasmodiophora brassicae in Japan tested with clubroot-resistant cultivars of Chinese cabbage (Brassica rapa L. ssp. pekinensis). Eur. J. Plant Pathol. 105:327-332.

20. McDonald, M. R., and Westerveld, S. M. 2008. Temperature prior to harvest influences the incidence and severity of clubroot on two Asian Brassica vegetables. Hort. Sci. 43:1509-1513.

21. Mithen, R., and Magrath, R. 1992. A contribution to the life history of Plasmodiophora brassicae: Secondary plasmodia development in root galls of Arabidopsis thaliana. Mycol. Res. 96:877-885.

22. Morgner, M., and Sacristán, M. D. 1995. Quantitative determination of colonization by Plasmodiophora brassicae (Wor.) in Brassica napus and
Brassica oleracea. Cruciferae Newsl. 17:80-81.

23. Sharma, K., Gossen, B. D., and McDonald, M. R. 2011. Effect of temperature on primary infection by Plasmodiophora brassicae and initiation of clubroot symptoms. Plant Pathol. 60:830-838. doi:10.1111/j.13653059.2011.02458.x.

24. Siemens, J., Nagel, M., Ludwig-Müller, J., and Sacristan, M. D. 2002. The interaction of Plasmodiophora brassicae and Arabidopsis thaliana: Parameters for disease quantification and screening of mutant lines. J. Phytopathol. 150:592-605.

25. Strelkov, S. E., Tewari, J. P., Smith, E., and Smith-Degenhardt, E. 2006. Characterization of Plasmodiophora brassicae populations from Alberta, Canada. Can. J. Plant Pathol. 28:467-474.

26. Takahashi, H., Ishikawa, T., Kaido, M., Takita, K., Hayakawa, T., Okazaki, K., Itoh, K., Mitsui, T., and Hori, H. 2006. Plasmodiophora brassicae induced cell death and medium alkalization in clubroot-resistant cultured roots of Brassica rapa. J. Phytopathol. 154: 156-162.

27. Tanaka, S., Ito, S. I., Kameya-Iwaki, M., Katumoto, K., and Nishi, Y. 1993. Occurrence and distribution of clubroot disease on two cruciferous weeds, Cardamine flexuosa and C. scutata, in Japan. Trans. Mycol. Soc. Jap. 34:381-388.

28. Thuma, B. A., Rowe, R. C., and Madden, L. V. 1983. Relationships of soil temperature and moisture to clubroot (Plasmodiophora brassicae) severity on radish in organic soil. Plant Dis. 67:758-762.

29. Tommerup, I. C., and Ingram, D. S. 1971. The life-cycle of Plasmodiophora brassicae Wor. in Brassica tissue cultures and in intact roots. New Phytol. 70:327-332.

30. Wallenhammar, A. C. 1996. Prevalence of Plasmodiophora brassicae in a spring oilseed rape in central Sweden and factors influencing soil infestation levels. Plant Pathol. 45:710-719.

31. Wellman, F. L. 1930. Clubroot of crucifers. Tech. Bull. USDA 18:1-31. 